\title{
Biostratigraphy of the Cretaceous deposits in the Western Transylvanides from Ampoi Valley (Southern Apuseni Mountains, Romania)
}

\author{
Ramona BALC*, Erika SUCIU-KRAUSZ \& Florin BORBEI \\ Department of Geology, „Babeş-Bolyai“ University, Kogălniceanu 1, 400084 Cluj Napoca, Romania
}

Received March 2006; accepted March 2007

Available online 5 September 2007

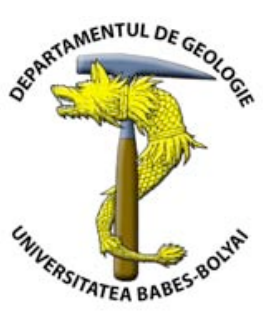

ABSTRACT. The present study is an approach of the issues related to the biostratigraphy of the Western
Transylvanides. The research provided exact age data for the Feneş Formation, Valea lui Paul Formation, Bozeş
Formation and Râmeți Formation. The age of the formations was established based on the calcareous
nannoplankton assemblages in Barremian-Campanian range. The lithological features together with the new age
data allowed us to modify the boundaries between formations; accordingly the knowledge on the structure of South
Apuseni Mountains required changes, too. The new data also imply the modification of the existent geological
maps of the region. Based on the identified calcareous nannoplankton assemblages, the following zones were
defined: CC6 - Late Barremian, CC9 - Lower Cenomanian, CC14 - Late Coniacian and CC17, CC18, and CC19
for Campanian.

Key words: Apuseni Mountains, Transylvanides, Cretaceous, biostratigraphy, calcareous nannoplankton.

\section{INTRODUCTION AND PREVIOUS STUDIES}

The Ampoi Valley geology has always represented an interesting topic for research. The most intense studies were carried out during the $4^{\text {th }}$ and the $7^{\text {th }}$ decades of the last century.

Gherman (1936) studied the deposits located south of Ampoi Valley; he pointed out the relations between the Senonian and Aptian and based on geometrical reasons he concluded that the age of the thrustings was post-Senonian and ante-Oligocene. Ilie (1950) thoroughly described the highly fossiliferous Albian, Cenomanian and TuronianSenonian sedimentary formations. Bleahu and Dimian (1963) studied the deposits from both south and north of Ampoi Valley. North of the valley they described two lithofacies as part of the Barremian-Aptian deposits: the stromatitic facies comprising a calcarenithic horizon with Orbitolina lenticularis, and the detritic-calcareous facies. They also delimited a ,wildflysch" lithological association including marly clay, calcirudite, grey-greenish compacted clays, green and purple sandy mica clays, parallel or oblique fine laminated arenites, calcarenites passing to marly limestones, of Cenomanian age. Two types of flysch were separated as part of the Bozeş Beds (Turonian-Senonian): a binary and a ternary one. A shift from distal (west) to proximal (east) facies was also noted (gradation from marl, to sandstones, microconglomerates and conglomerates). In 1967 the same authors have ascribed the Barremian-Aptian deposits exhibiting a schistose litofacies to the Feneş Formation (Lower Feneş beds). The Feneş Formation consists of silty and silty clayey schists, affected by low degree metamorphism. Above these deposits, Bleahu and Dimian (1967) mentioned wildflysch deposits attributed to
Meteş beds (Late Aptian - Albian, possibly Cenomanian). Berbeleac (1968) separated basalts, agglomerates, tuffs and cinerites as part of the ophiolitic complex. He considered that Jurassic limestones may appear in the region both in situ, and as olistoliths. Antonescu (1973) studied the palinologic assemblages from various formations belonging to South Apuseni Mountains and provided new data on their palaeontology and stratigraphy. He assigned the deposits from Fierului Brook, previously known as Aptian, to Bozeş beds (Turonian-Santonian). In the Galda de Sus - Poiana Aiudului region, Antonescu (1974) pointed out the presence of Late Cretaceous (Late Cenomanian-Turonian-Santonian) wildflysch and flysch deposits.

During the last twenty years, a few investigations were made in the area because of its structural complexity and lack or insufficiency of paleontological data.

We present the results of the research carried out during the summer of 2005 along the Ampoi Valley. This study concerns the stratigraphy of the region and the affiliation of the deposits to the already separated formations, based on their calcareous nannoplankton assemblages.

\section{LOCATION AND GEOLOGICAL SETTING}

The study area is located in central-western Romania and belongs to the Southern Apuseni Mountains (Fig. 1).

The Apuseni Mountains originate from the Preapulian Craton (Săndulescu, 1994) and from the Transylvanian Tethys (Săndulescu, 1984) and include the Transylvanides and the Apusenides. During the Early Miocene, the Apuseni Mountains were separated from the Western Carpathians and the Austrian Alps through the central-Hungarian 
transform faults (Kovács, 1982; Kováč et al., 1993). The south-easternmost one represents the northwest border between the Tisia block and the Szolnok Flysch (Kovács, 1982). The Szolnok fault also separates the Transylvanides from the Pienides (Balintoni, 1997). Three deformation periods affected the Apuseni Mountains: Austrian, Pregosau and Laramian (Bleahu et al., 1981).

The Transylvanides were emplaced during the Austrian tectonic phase and reworked during the Laramian one. The Pregosau tectonic phase sheared only the Apusenides (Bleahu et al., 1981, Balintoni, 1997).

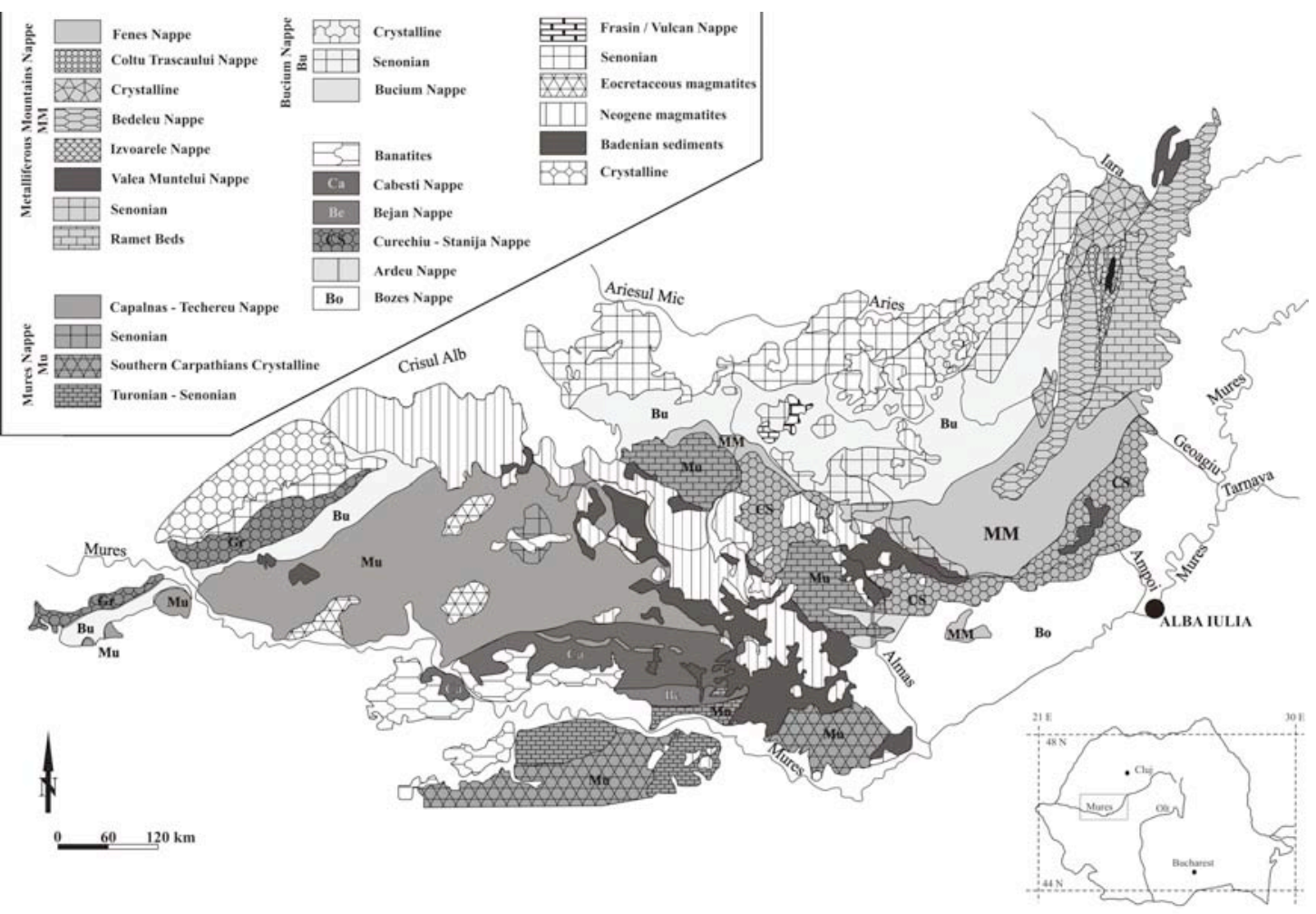

Fig. 1. Geological sketch of the studied area (after Balintoni, 1997, modified).

The studied cross-sections crop out along to a series of southern and northern tributaries of Ampoi Valley (a western tributary of Mureş River, which it joins near AlbaIulia city). These tributaries are: Bobului, Satului, Presaca Ampoiului, Galați, Valea Mică, Valea Mare, Fața Furilor, Trâmpoiele brooks (on the south side) and Fierului, Călineasa (east side tributary of Feneş), Feneş, Valea lui Paul, Vâltori, Ruzi/Pietrei and Slatinii brooks (on the northern side).

Ampoi Valley and its tributaries cross several tectonic units belonging to the Western Transylvanides (Bleahu et al., 1981): Feneş, Valea Mică - Galda, Bozeş Nappes, and Râmeți Formation (post-Austrian cover of Bedeleu Nappe). Balintoni (1997) questioned the existence of Valea Mică Galda Nappe; subsequently he redefined the Bozeş Nappe as being a Laramian tectonic unit consisting of Bozeş Formation, Rapolt crystalline, Poiana Ruscă crystalline and Bejan Unit (Balintoni, 2003). He assigned this nappe to the Southern Carpathians, and not to the Apuseni Mountains.

In this study we use the structural classification of the Western Transylvanides proposed by Bleahu et al., (1981), thus, the Feneş Nappe comprises (Lupu, 1975):

The Feneş Formation (Bleahu and Dimian, 1967, redefined by Lupu et al., 1978) was described as a volcanosedimentary-calcareous olistostrome with flysch sequences. It begins with a thick sequence of quartz sandstones and gray clays, which show olistostrome feature at the upper part, marked by slumped clays with interbedded tuffs and spilitic lavas. Some bioconstructed massive, but more often thin bedded micritic limestones showing some stromatitic character are observed in the succession. The age of the formation is Barremian - Aptian (Bleahu et al., 1981).

The Meteş Formation (Bleahu and Dimian, 1967) overlies the Feneş formation and has a typical wildflysch character. It is latest Aptian - Middle Albian in age and consists of two members: a lower one, characterized by an olistostrome-like marly-silty facies with some interbedded turbiditic and thick layered sandstones, and an upper member which consists of breccias with silty-marly matrix and olistholits representing Upper Jurassic limestones, ophiolitic and granodioritic rocks, and Early Cretaceous sandstones (Bleahu et al., 1981).

The Valea lui Paul Formation (Bleahu and Dimian, 1967) has a prevalent detrital, coarse grained character, with gray loose sandstones grading into sands. The flysch-like rhythmic sequences are present, but the beds are often thick. The Latest Albian - Cenomanian age of the formation was established based on palaeontological characteristics (foraminifera and pollen) (Bleahu et al., 1981).

The Valea Mică - Galda Nappe (Lupu et al., 1979) consists of a Senonian wildflysch megabreccia formation. The olistoliths belonging to the basic rocks and Upper Jurassic limestones are typical. The age of the formation is Turonian - Lower Senonian (Drăgănescu in Bleahu et al., 1981). Valea Mică-Galda Nappe overthrusts the Feneş Nappe and is overthrusted by the Bozeş Nappe (Bleahu et al., 1981).

The Bozeş Nappe (Lupu et al. in Bleahu et al., 1981) represents the uppermost unit among the western Transylvanides and it crops out in the south of the Southern 
Apuseni Mountains. The main litostratigraphical component of the nappe, i.e. the Bozeş Formation (Ghițulescu and Socolescu, 1941) is a typical flysch formation, lithologic types of successions being separated: (1) sandstones, limy sandstones and silty marls, and (2) microconglomerates, sandstones and silty marls. The Santonian age of the sequence is supported by microfaunal data (Dimian and Dimian, 1964; Marincaş, 1973). Above the flysch-like sequence, conglomeratic levels occur interbedded with silty sandstones of Campanian - Maastrichtian age (Bleahu et al., 1981).

The Râmeți Formation (Bordea et al., 1968) consists of coarse polymictic conglomerates, quartz sandstones and marls, with olistoliths of Stramberk-like limestones. The age of the formation is considered to be Cenomanian-Danian based on macro- and microfauna.

\section{METHODS}

About 240 samples for calcareous nannoplankton analyses were collected from the studied cross-sections. The samples were prepared by using the standard smear slide technique for light microscope (LM) observation. The investigations were carried out under a light microscope (Nikon Optiphot2 - Pol) at a magnification of 1000x using parallel and crossed nicols.

For biostratigraphic purposes the standard nannoplankton CC zones by Sissingh (1977) and PerchNielsen (1985) were used together with BC zones (Early Cretaceous nannofossil Zones) introduced by Bown et al. (1998), and UC zones (Late Cretaceous nannofossil Zones) introduced by Burnett (1998).

\section{RESULTS}

The sixteen logs built-up from the studied valleys represent the beginning of a biostratigraphical research based on calcareous nannoplankton analyses. The present study uses only the cross-sections that provided data on the calcareous nannoplankton assemblages (six cross-sections south and one north of Ampoi Valley). An attempt was made to separate the formations (both lithologically and biostratigraphically) and to correlate them from east towards west, based on the current data (Suciu-Krausz et al., 2006). Changes in the stratigraphy of the area were also marked.

A marker level intercepted in four cross-sections (south of Ampoi Valley) consisting of Late Jurassic basic magmatic rocks (Cioflică et al., 1981) lays above the Early and lower Upper Cretaceous deposits, thus confirming the Laramian thrusting in the Southern Apuseni Mountains. Early Cretaceous deposits beneath the marker level exhibit mostly a wildflysch character; the matrix sustaining the olistoliths is not visible. Thick Late Cretaceous deposits crop out above the magmatic rocks and can be correlated in all the cross-sections, providing valuable information on the base of the nappe comprising them. Late Cretaceous deposits were also intercepted in the Fierului Brook crosssection, previously mentioned by Antonescu (1973).

We present our data according to the chronostratigraphical succession.

At the base of the Valea Satului cross-section (P2), compact, hard, reddish-greenish and black clays crop out, exhibiting visible friction mirrors above which a level of sandstones was deposited. The presence of friction mirrors within the clays suggests the influence of tectonic movements. The assemblage of calcareous nannoplankton identified in the clays is well preserved and diverse. The species belong to the genera Watznaueria $(W$. barnesiae, $W$. britannica, $W$. ovata), Nannoconus (N. steinmannii, $N$. kamptneri, N. ligius, N. quadricanalis, N. bucheri), and Micrantolithus (M. hoschulzii, M. obtusus). Rarely, species of the genera Zeugrhabdotus, Retecapsa and Rhagodiscus appear. Based on the presence of Micrantolithus hoschulzii, the studied deposits can be attributed to the CC6 Zone, defined as the interval between the last occurrence (LO) of Calcicalatina oblongata and the first occurrence (FO) of Chiastozygus litterarius (Sissingh, 1977; Perch-Nielsen, 1985). The bioevent marking the top of the zone was not identified in the analyzed section. According to Bown et al. (1998), this zone could be correlated with the BC15 zone (Zeugrhabdotus scutula Zone), defined by the common to frequent presence of the index taxa. The age of these deposits is Late Barremian.

The gray-reddish and gray-greenish clays with olistoliths intercepted in the Presaca Ampoiului (P3), Galați (P4) and Valea Mică (P5) sections totally lack calcareous nannoplankton. According to the studies carried out by Bleahu and Dimian (1967) and Lupu et al. (1967), the deposits belong to the Late Aptian - Middle Albian.

Above these deposits, in the Galati cross-section, a calcareous nannoplankton assemblage was identified in grayish-reddish clays, dominated by Watznaueria barnesiae, Tranolithus orionatus and Retecapsa crenulata. These deposits have been attributed to the Early Cenomanian. Eiffelithus turriseiffelii indicates the CC9 Zone, defined as the interval between the FO of Eiffelithus turriseiffelii and the FO of Microrhabdulus decoratus (Sissingh, 1977; Perch-Nielsen, 1985). The bioevent indicating the top of the zone was not identified in the studied deposits. It would correspond to the $\mathrm{BC} 27$ zone (Eiffelithus turriseiffelii Zone) defined as the interval between the FO of Eiffelithus turriseiffelii and the FO of Corollithion kennedyi (Bown et al., 1998). The presence of Corollithion kennedyi and the lack of Litraphidites acutus and Gartnerago segmentatum may also suggest an Early Cenomanian age. The species Zeugrhabdotus embergeri, Z. diplogrammus, Z. scutula, Z. erectus, and $Z$. elegans are well represented here.

Late Cretaceous sedimentary deposits crop out on wide areas south of Ampoi Valley, laying above the Late Jurassic magmatic rocks marker level. They were intercepted in the sections of Bobului (P1), Satului (P2), Presaca Ampoiului (P3), Galați (P4), Mică (P5) (and its tributary, Valea Mare P6) brooks. The deposits consist of a rhythmical succession of sandstones with clays/marls and conglomerates/microconglomerates. Clays/marls are gray or gray-reddish to black, millimeters to centimeters thick. Under the microscope, quartz (of metamorphic origin), muscovite / biotite, chlorite, opaque iron and manganese oxides, and plagioclase were noticed. Organic matter is also present. Conglomerates contain rounded centimetric to decimetric clasts of sandstones, bioclastic limestone, quartzite and also magmatic (dolerite, chloritised acidic rocks), or metamorphic (heteroblastic quartzite) rocks (fragments). Sandstones are arenitic, with carbonate cement and include angular to subrounded fragments of lithic components (doleritic spillites, quartzite, micaschists and quartz-actinolite schist), bioclasts (sponge spicules, 
foraminifera) and crystaloclasts (quartz, altered plagioclase, muscovite/biotite, chlorite, epidote, rarely apatite, tourmaline, glauconite, titanite). The presence of polycrystalline silica "spheres" can also be noticed with no source information for the moment.

A rich, well-preserved association of calcareous nannoplankton was identified in the Late Cretaceous clays. The age of the deposits was determined and the sections were correlated. CC17 Zone (Calculites obscurus Zone) and CC18-CC19 Zone (Broinsonia parca - Calculites ovalis Zone) were identified indicating the Early Campanian.

The CC17 Zone (Lower Lower Campanian) was identified in the sections from Bobului (P1) and Mica (P5) brooks, dominated by Watznaueria barnesiae, Retecapsa crenulata, Cribrosphaerella ehrenbergii, Eiffelithus eximius, Prediscosphaera cretacea, and Tranolithus orionatus. A high frequency of Nannoconus and Braarudosphaera species was also noted. A bloom of these species was mentioned by Cunha and Shimabukuro (1997) and Švábenická (1999) but at earlier stages during Turonian, from the Santos Basin (Brazil) and, respectively the Bohemian Basin. Thus, a possible cause for the blooming could be the decrease of salinity accompanied by the eutrophication due to a high influx of continental waters rich in nutrients (Cunha and Shimabukuro, 1997; Švábenická, 1999). This interval could be correlated with UC13 Zone defined by the interval between the FO of Arkhangelskiella cymbiformis and the FO of Broinsonia parca parca (Burnett, 1998).

The first occurrence of Broinsonia parca parca and its presence together with Calculites ovalis in the sections studied from Satului (P2), Presaca Ampoiului (P3), Galați (P4), and Mare (P5) brooks provide obvious data sustaining the presence of $\mathrm{CC} 18-\mathrm{CC} 19$ Zones. Based on the identified nannoplankton assemblage and the presence of the index taxa, the deposits were ascribed to the middle Early Campanian - late Early Campanian. The base of the CC19 Zone (characterized in Sissingh's Scheme by the LO of the nannofossil Marthasterites furcatus) has not been identified in the deposits from Galați, Presaca Ampoiului, and Mică brooks due to the reworkings of the index taxa. A similar situation was noted in an area NW of Hateg (Grigorescu and Melinte, 2002), or in north Israel (AlmogiLabin et al., 1991). The dominant species (Watznaueria barnesiae, Retecapsa crenulata, Cribrosphaerella ehrenbergii, Eiffelithus eximius, Prediscosphaera cretacea, and Tranolithus orionatus) are accompanied by Arkhangelskiella cymbiformis, Helicolithus trabeculatus, and Broinsonia spp., Zeugrhabdotus spp., Russellia spp., Prediscosphaera spp.

Fierului Brook (Fig. 2) is the only cross-section from the north side of Ampoi Valley that provided micropalaeontological data (calcareous nannoplankton) although all the other cross-sections were systematically sampled. Both individuals and species of calcareous nannoplankton are poorly represented in the samples collected from the base of this section. The identified taxa have a broad distribution throughout the Cretaceous; therefore the exact age of the deposits cannot be established. But the lack of any Late Cretaceous taxa suggest a Lower Cretaceous age as defined on the 1:200 000 geological map, Turda sheet (Lupu et al., 1967).

The calcareous nannoplankton assemblage identified in the middle part of the section shows a moderate preservation status, with numerous fragmented and crystallized specimens. According to the biozonation schemes of Sissingh, 1977 and Perch-Nielsen, 1985, these deposits belong to the CC18 zone (Broinsonia parca Zone) defined by the interval from the FO of Broinsonia parca to LO of Marthasterites furcatus. The bioevent marking the top of the zone has not been identified, based on the presence of Marthasterites furcatus in all the analyzed samples. The species Bukryaster hayii and Ceratolithoides verbeekii used by Sissingh, 1977 and Perch-Nielsen, 1985 to subdivide CC18 zone into two subzones, are both missing. The age of the deposits is Early Campanian and not Early Cretaceous (Barremian - Early Aptian) as specified on the geological map (Lupu et al., 1967).

The biozonation schemes of Burnett, 1998 cannot be applied in this case because of the lack of marker taxa for the UC14 and UC15 zones for Lower Campanian. The assemblage is dominated by Watznaueria barnesiae, Cribrosphaerella ehrenbergii, Retecapsa crenulata, Tranolithus orionatus, and Eiffelithus eximius. Besides the mentioned species, also Arkhangelskiella cymbiformis, Zeugrhabdotus spp., Broinsonia spp., Prediscosphaera spp. are common.

These deposits can be correlated with the northern ones (Galda Brook - western tributary of Mureş River) in which the calcareous nannoplankton assemblage indicated the same Late Cretaceous age. The assemblage is poorer in species and individuals and moderately preserved. Twenty species were identified. The Late Coniacian age (CC14 Micula staurophora Zone) is proven by the presence of Micula straurophora.

Badenian deposits (possibly NN5 Zone) containing the following calcareous nannoplankton species: Sphenolithus heteromorphus, Helicosphaera spp., Coccolithus spp., and Reticulofenestra spp have been identified on the top of the section.

\section{DISCUSSION}

The lack of palaeontological data has always been an important issue in understanding and clarifying the stratigraphy of the South Apuseni Mountains. Some crosssections situated north of Ampoi Valley raised the same problems. Their biostratigraphical correlation was not possible, a lithostratigraphical correlation being attended (Suciu-Krausz et al., 2006.). The separation of deposits based on their similitude with already defined units is not always accurate. This applies to the deposits from Fierului to Galda brooks (located northwards), which were described as part of Feneş Formation (Barremian-Aptian) (Bleahu and Dimian, 1963). Based on the latest data obtained during our research, we assigned the deposits to the Râmeți Formation (Cenomanian - Danian), which has to be prolonged towards south, to the Ampoi Valley. The older age from north (Galda Valley) and the newer one from south (Fierului brook) prove the deepening of the basin towards south.

The Feneş Formation has a great extent north of Ampoi Valley. Its identification for the first time in the section from Satului brook (south of Ampoi Valley) pleads for the extension and shifting of its margins towards southeast.

An open question remains though the absence or bad preservation of calcareous nannofossils in the deposits belonging to Meteş Formation (Late Aptian -Middle Albian according to Bleahu and Dimian, 1967, Lupu et al., 1967). 


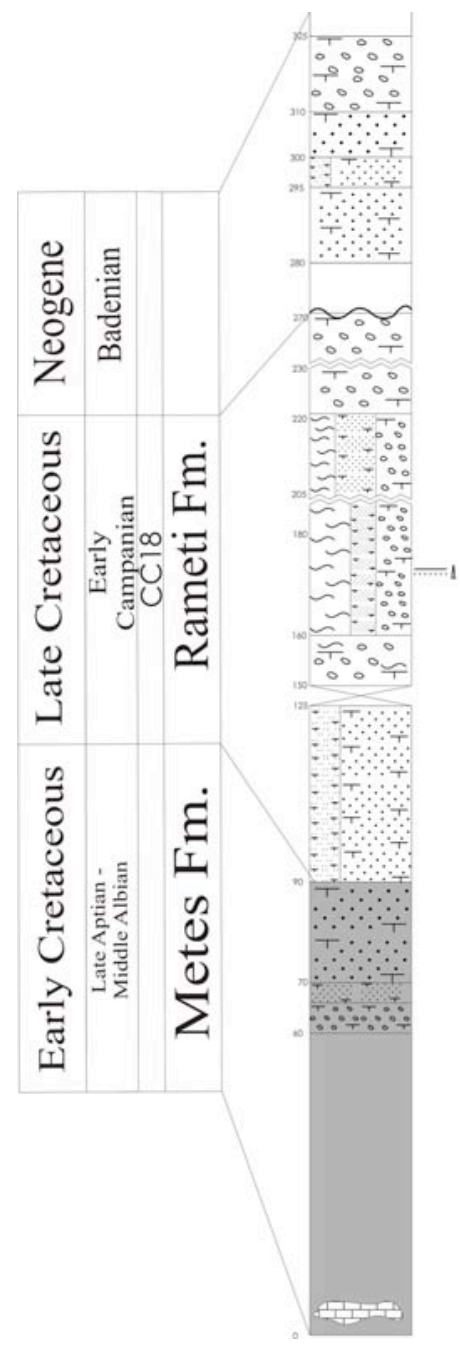

Fig. 2. Cross section for Fierului brook.
In the Galați brook section, the Valea lui Paul Formation (Early Cenomanian) is situated above the Meteş Formation. It constitutes the only location, which provided paleontological data on this formation. On Valea lui Paul brook, where the formation was first described, our research indicates the total lack of calcareous nannofossils because of yet unknown reasons. The total substitution of calcium carbonate by dolomite was noted in these deposits (SuciuKrausz et al., 2006).

The Late Cretaceous deposits south of Ampoi Valley belong to Bozeş Formation. According to the 1:50.000 geological map of Romania, Zlatna sheet (Borcoş et al., 1981) the forehead of Bozeş Nappe ends in Mică Brook, although it was proved both lithologically and paleontologically that it had to be shifted towards west together with the deposits from the left side tributaries of Valea Mică brook. Thus, Valea Mică-Galda Formation has to be spatially restrained because field data do not point to any lithological differences between Bozeş beds and what was described as Valea Mică-Galda Formation, along the Valea Mică brook.

A shift from the western distal to the eastern proximal facies is noticed among the Bozeş beds as emphasized by the gradual transition from clay/marls to conglomerates. The higher abundance of the species of Braarudosphaera and Nannoconus in the cross-sections from Satului and Bobului brooks (located easternmost in the studied area) than in other occurrence areas of Bozeş beds adds arguments to the same hypothesis. These species prefer low salinity environments with abundant nutrients like coastal environments, where influx of continental waters leads to decrease in salinity and enrichment in nutrients (Cunha and Shimabukuro, 1997; Švábenická, 1999).

Based on the recent data, a possible correlation between the cross-sections can be done (Fig. 3).

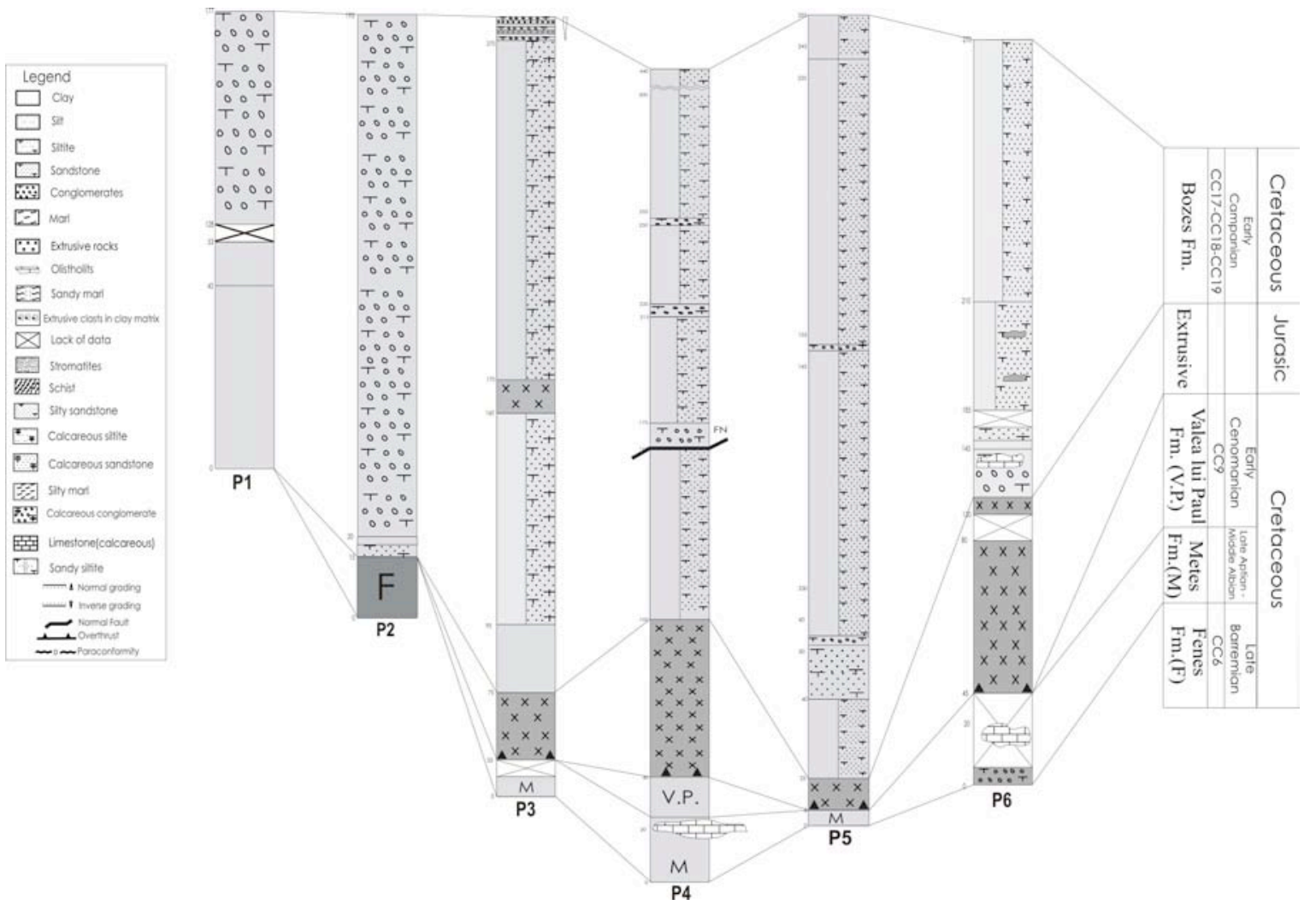

Fig. 3. Correlation of studied cross sections. 


\section{CONCLUSIONS}

Based on the calcareous nannoplankton assemblages the following $\mathrm{CC}$ zones were determined: CC6, CC9, CC14, CC17, CC18 and CC19. Their stratigraphic positions allow us to assign the studied sections to Feneş (Upper Barremian), Valea lui Paul (Lower Cenomanian) and Bozeş (Lower Campanian), and Râmeți (Coniacian, Lower Campanian) Formations.

Lithologic sections were correlated and compared with the map drawn by Bleahu and Dimian (1967). The Meteş Formation (Upper Aptian - Albian) was identified, with no paleontological arguments, according to the above mentioned map.

The Feneş Formation has been identified for the first time as part of Satului Valley lithological section. The (lithological) observations from the south side tributary of Mică Valley (Mare Valley) supported by micropalaeontological data prove the extension toward NW of the Bozeş Nappe implying the restraint of the Valea Mică-Galda Formation.

Acknowledgments. The authors are grateful to Prof. Ioan Balintoni for his help in making this study possible. Also, our thanks go to Dr. Dana Pop for her help regarding the English adaptation. We would also like to thank all those who joined us in the field throughout the summer of 2005: Corina Fuer, Luminița Zaharia, Constantin Balica, and Cosmin Stremțan.

\section{R E F E R E N C E S}

Almogi-Labin, A., Eshet, Y., Flexer, A., Honigstein, A., Moshkovitz, S. \& Rosenfeld, A. 1991, Detailed biostratigraphy of the Santonian/Campanian boundary interval in Northern Israel. Journal of Micropaleontology, 10 (1): 39-50.

Antonescu, E. 1974, Palinostratigraphical data on the Cretaceous deposits from Galda de Sus - Poiana Aiudului area, Metalifferous Mountains. Dări de Seamă ale Institutului de Geologie şi Geofizică, LX (4) (19721973): 25-49 (in Romanian).

Antonescu, E. 1973, Palinologic assemblages characteristic to some Cretaceous formations from Metalifferous Mountains. Dări de Seamă ale Institutului de Geologie, LIX (3): 115-169 (in Romanian).

Balintoni, I. 1997, Geotectonics of the metamorphic terrains in Romania. Ed. Carpatica, Cluj Napoca, 176 p. (in Romanian).

Balintoni, I. 2003, Towards an improved model of the Laramian Transylvanides. Studia Universitatis BabeşBolyai, Geologia, Special Issue, p. 13-20.

Berbeleac, I. 1968, Eruptive rocks reworked in Lower Cretaceous deposits from Valea Micş - Galați - Presaca Ampoiului area (Metaliferi Mountains). Dări de Seamă ale Şedințelor, (1966-1967), LIV (1): 15-26 (in Romanian).

Bleahu, M., Dimian, M. 1963, Stratonomic charactersistics of the Cretaceous series from Metalifferous Mountains. Proceedings of the $\mathrm{V}^{\text {th }}$ Congress of the CarpathoBalkanic Geological Association (1961), III (1): 81-95 (in Romanian).

Bleahu, M., Dimian, M. 1967, Stratigraphic and tectonic studies in Feneş - Ighiel - Întregalde area (Metaliferi
Mountains). Dări de Seamă ale Comitetului de Stat Geologic, LIII (1): 281-304 (in Romanian).

Bleahu, M., Bordea, S., Lupu, M., Ştefan, A., Patrulius, D., \& Panin, S. 1981, The structure of the Apuseni Mountains. Guide to Excursion B3, XII Congress of the Carpatho-Balkan Geological Association, Bucharest, 107 p.

Borcoş, M., Berbeleac, I., Bordea, S., Bordea, J., Mantea, G. \& Boştinescu, S. 1981, Geological map of Romania, scale 1:50 000, sheet Zlatna. Institutul de Geologie şi Geofizică, Bucureşti.

Bordea, S., Bordea J., Georgescu, V., Mantea, G. \& Puricel, R. 1968, On the presence of a Hauterivian fauna in Cetea - Pleaşa calcareous massiff from Galda - Rameti area. Dări de Seamă ale Comitetului de Stat Geologic, (19661987), LIV (1): 223-237 (in Romanian).

Bown, P.R., Rutledge, D.C., Crux, J.A. \& Gallagher, L.T. 1998, Lower Cretaceous. In Calcareous Nannofossil Biostratigraphy (Bown, P.R. Ed.), British Micropaleontological Society Publication Series, Chapman and Hall Ltd/Kluwer Academic Press, p. 86-198.

Burnett, J.A. 1998, Upper Cretaceous. In Calcareous Nannofossil Biostratigraphy (Bown, P.R., Ed.), British Micropaleontological Society Publication Series, Chapman and Hall Ltd/Kluwer Academic Press, p. 132-199.

Cioflica, G., Savu, H., Nicolae, I., Lupu, M. \& Vlad, Ş. 1981, Alpine Ophiolitic Complexes in South Carpathians and South Apuseni Mountains. Guide for excursion A3, Carpatho-Balkanic Geological association XII Congress, Institute of Geology and Geophysics, 18: 1-80.

Cunha, S., Shimabukuro, S. 1997, Braarudosphaera blooms and anomalous enrichments of Nannoconus: evidence from the Turonian South Atlantic, Santos Basin, Brazil. Journal of Nannoplankton Research, 19 (1): 51-55.

Dimian-Popa, E., Dimian, M. 1964, Stratigraphical and sedimentological data on the Cretaceous formations between Mureş and Ampoi Valleys. Dări de Seamă ale Comitetului Geologic, (1961-1963), L (1): 107-130 (in Romanian).

Gherman, I. 1936, Post-senonian overthrustings in Ampoi Basin. Museum of Geology and Mineralogy, VI (1): 345-348 (in Romanian).

Ghițulescu, T.P., Socolescu, M. 1941, Étude géologiques et minière des Monts Metalliferes. Anuarul Institutului Geologic, XXI: 181-463.

Grigorescu, D., Melinte, M.C. 2002, The stratigraphy of the Upper Cretaceous marine sediments from the NW Hațeg Area (South Carpathians, Romania). Acta Palaeontologica Romaniae, III: 153-159.

Ilie, D.M. 1950, Monts Metalliferes de la Roumanie. Annuaire Institute Geologique Roumaine, XXIII: 121-176.

Kováč, M., Nagymarosy, A., Soták, J. \& Šutovská, K. 1993, Late Tertiary paleogeographic evolution of the Western Carpathians. Tectonophysics, 226: 401-415.

Kovács, S. 1982, Problems of the "Pannonian Median Masif" and the Plate Tectonics Concept. Contributions Based on the Distribution of the Late Paleozoic Early Mesozoic Isotopic Zones. Geological Rundschau, 71 (2): 617-640.

Lupu, M. 1975, Einige bemerkungen zur Tektonik des südlichen Apuseni Gebirge (Siebenbürgisches Erzgebirge). Revue Roumaine de Geologie, Geophysique, Geographique, Serie de Geologie, 19: 95-104.

Lupu, M., Borcoş, M., Dimian, M, Lupu, D. \& Dimitrescu, R. 1967, Geological map of Romania, scale 1:200.000, 
sheet Turda. Comitetul de Stat Geologic, Bucureşti.

Lupu, D., Sornay, J. 1978, New biostratigraphical data on the Senonian from Vidra area (Metalifferous Mountains). Studii şi cercetări geologice, geofizice şi geografice, (Geologie), 23 (1): 73-82.

Lupu, M., Berbeleac, I., Ştefan, A. \& Papaianopol, F. 1979, Geological map of Romania, scale 1: 50.000, sheet Hălmagiu. Institutul de Geologie şi Geofizică, Bucureşti.

Marincaş, V. 1973, The age of Bozeş Beds. Studia Universitatis Babeş-Bolyai, 1: 39-46.

Perch-Nielsen, K. 1985, Mesozoic calcareous nannofossils. In Plankton Stratigraphy (Bolli, H.M., Saunders, J.B., Perch-Nielsen, K., Eds.), Cambridge University Press, p. 329-426.
Săndulescu, M. 1984, The Geotectonics of Romania. Ed. Tehnică, Bucureşti, 336 p. (in Romanian).

Săndulescu, M. 1994, Overview on Romanian Geology. Romanian Journal of Tectonics and Regional Geology, 75 (2): 3-15.

Sissingh, W. 1977, Biostratigraphy of Cretaceous calcareous nannoplankton. Geologic Mijnbouw, 56: 37-65.

Suciu-Krausz, E., Balc, R. \& Borbei, F. 2006, New data on the Western Transylvanides along Ampoi Valley (Southern Apuseni Mountains). Studia Universitatis Babeş-Bolyai, Geologia, 51 (1-2): 55-60.

Švábenická, L. 1999, Braarudosphaera - rich sediments in the Turonian of the Bohemian Cretaceous Basin, Czech Republic. Cretaceous Research, 20: 773-782. 